\title{
Identification of calcified atheromatous plaques from patients attending a dental clinic unit in León, México
}

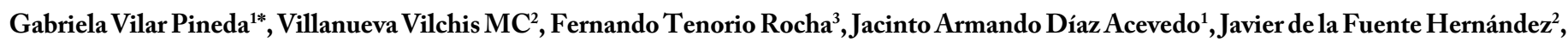
and Benjamín Sánchez Trocino ${ }^{1}$

${ }^{1}$ Departamento de Cirugía Oral y Maxilofacial ENES León de la UNAM, Mexico

${ }^{2}$ Departamento de Patología Oral y Maxilofacial ENES León de la UNAM, Mexico

${ }^{3}$ Departamento de Salud Pública y Epidemiología ENES León de la UNAM, Mexico

\begin{abstract}
Atherosclerosis is a chronic inflammatory process that affects the arteries of different vascular beds. The most common site is the origin of the internal carotid. It is estimated that $50 \%$ of strokes are caused by atherosclerotic plaques. Panoramic radiographs are routine and inexpensive radiographic studies that allow us to observe flatly dental structures, maxillary and mandibular. Friendlander in 1981 published for the first time the possibility of identifying through panoramic radiographs atherosclerotic plaques calcified at this bifurcation giving importance of this study the opportunity for early detection of this disease.
\end{abstract}

Objective: To determine the prevalence of carotid calcifications in 316 patients admitted to clinic admission of the Escuela Nacional de Estudios Superiores, Unidad León, Universidad Nacional Autónoma de México (UNAM).

Results: Consistent findings were obtained with atheroma calcified carotid in 7 patients with which it is concluded on the importance of training of imaging diagnosis undergraduates for early diagnosis and prevention of stroke in patients at risk of stroke.

\begin{abstract}
Abbreviations: CVA: Cerebral vascular accident
\section{Introduction}

Atherosclerosis is a chronic inflammatory process that affects the arteries of different vascular beds and is characterized by thickening of the intima and media layer with loss of elasticity. The basic lesion is the atheromatous plaque, composed mainly of lipids, fibrous tissue and inflammatory cells, which thickens, hardens, and may eventually block the arteries light [1].
\end{abstract}

The most common place where atherosclerosis occurs is the origin of the internal carotid, estimating that $50 \%$ of cerebral vascular accidents (CVA) are caused by atherosclerotic plaques in that location [2].

The presence of carotid atheroma is associated with the severity of coronary artery disease and stroke (CVA) [1].

The World Health Organization (WHO) considers CVA as the third leading cause of death worldwide and a major cause of disability in North America, Europe and Asia [3]. According to the statistics of mortality in Mexico, the CVA is part of the top ten causes of death in our country. In the United States of America (USA) is considered that the number of new cases per year is 500,000 to 700,000 , the cost of care amounted to 30 billion dollars, without generating disability and deaths, which are approximately 200,000 among cases [4].

The frequency of occurrence increases with age and with the elderly of population, so it is believed that by 2030 the numbers of deaths will double CVA.

Given these figures is important to establish measures for prevention and control of the risk factors. Epidemiological studies have revealed that there are environmental and genetic factors associated with atherosclerosis.

Moreover, the search for a reliable and economic system for the detection of patients at risk of suffering a stroke is based on the identification [3].

Friendlander [5] published the ability to identify through panoramic calcified atherosclerotic plaques at this bifurcation as these can provide images as nodular masses radiopaque or radiopaque two adjacent vertical lines or just below the intervertebral space $\mathrm{C} 3$ and $\mathrm{C} 4$ [6].

The orthopantomography is an imaging test that allows to observe bilaterally all dental and maxillofacial structures in a flat image, besides being fast processing and low cost, is considered as a fundamental tool for mass assessment and preventive diagnosis of disorders in the maxillofacial region so it can be use to demonstrate the presence of carotid calcifications. It is an ideal alternative [1] as close to the pharynx at the area of the carotid bifurcation and these lesions atheromas appear when partially calcified are visible [7].

Although the utility of this study for the detection of calcified

Correspondence to: Gabriela Vilar Pineda, Educación Continua e Intercambio Académico, ENES unidad León, UNAM, Mexico, Tel: 01 (477) 19408 00; E-mail: gvilar@unam.mx

Key words: atheromatous plaques, stroke, ortopantomography

Received: March 20, 2015; Accepted: April 25, 2015; Published: April 28, 2015 
carotid atheroma is clear [8] has some limitations such as requiring that the study covers the location of the carotid bifurcation, in addition to training the dentist for interpretation and understanding of the differential diagnosis because there are other structures and conditions that may occur as radiopaque side looking like tritíceo cartilage, hyoid bone, styloid process, calcification of the stylohyoid and stylomandibular ligament, calcification of the thyroid cartilage, epiglottis, soft palate, tongue, ear lobe, the anterior spinous process of the atlas, the cervical vertebrae, calcified lymph nodes, phleboliths, sialoliths, tonsolitos and calcified acne [9], what is important training the student's degree in dentistry for proper detection and prevention.

The purpose of this retrospective study was to determine the prevalence of carotid calcifications in 316 patients admitted to clinic admission of the Escuela Nacional de Estudios Superiores, Unidad León using orthopantomographies.

\section{Methods}

It is a cross-sectional study about the incidental findings of calcified atheromatous plaques in routine orthopantomographies of 316 patients that attend the Admission Clinic of the ENES, León in the period of October, 2013 to February, 2014.

Patients from 18 to 50 years of age were included and were excluded those patients with controlled or uncontrolled systemic diseases as well as systemic symptomatology and dental pain symptoms.

As a part of the admission process, a sociodemographic interview was performed to each patient, as well as a complete anamnesis. Finally, an orthopantomography was taken to each patient by a standardized operator of the imagenology equipment (Orthopantomograph OP200D, Orthocep, OC200D, Instrumentarium Dental, US).

Each orthopantomography was analyzed to identify the calcified atheromatous plaques by one expert using a 20" screen computer, LCD color S2032, 1600x900 pixels resolution, Hewlet Packard US.

The identification parameters corresponded to the radiopaque findings (radiopaque nodules or radiopaque lines either unilateral or bilateral) adjacent to the intervertebral space between C3 and C4.

Following the guidelines of the General Health Law in México, each patient signed a format of informed consent, through which the institution was committed to give accurate and relevant information to each patient and to respect the right to privacy.

\section{Results}

The orthopantomographies of 316 patients were analyzed. The mean each of the patients was $33.7 \pm 22.62$ years, $39.2 \%$ (124) were females while $60.7 \%$ were males. The carotid calcifications prevalence was of $2.2 \%$ (7) and all these cases were in women, with a mean age of 31.8 years.

In the seven orthopantomographies with carotid calcifications, $57.1 \%$ (4) were bilateral and (42.9\%) 3 unilateral (Table 1) (Figure 1).

Table 1. Location of the calcified atheromatous plaques.

\begin{tabular}{|c|c|c|c|c|}
\hline Patient No. & RN & RL & Unilateral & Bilateral \\
\hline $\mathbf{1}$ & & $\mathrm{x}$ & & $\mathrm{x}$ \\
\hline $\mathbf{2}$ & & $\mathrm{x}$ & $\mathrm{x}$ & \\
\hline $\mathbf{3}$ & $\mathrm{x}$ & & $\mathrm{x}$ & \\
\hline $\mathbf{4}$ & $\mathrm{x}$ & & $\mathrm{x}$ & \\
\hline $\mathbf{5}$ & & $\mathrm{x}$ & & $\mathrm{x}$ \\
\hline $\mathbf{6}$ & $\mathrm{x}$ & & & $\mathrm{x}$ \\
\hline $\mathbf{7}$ & $\mathrm{x}$ & & & $\mathrm{x}$ \\
\hline
\end{tabular}
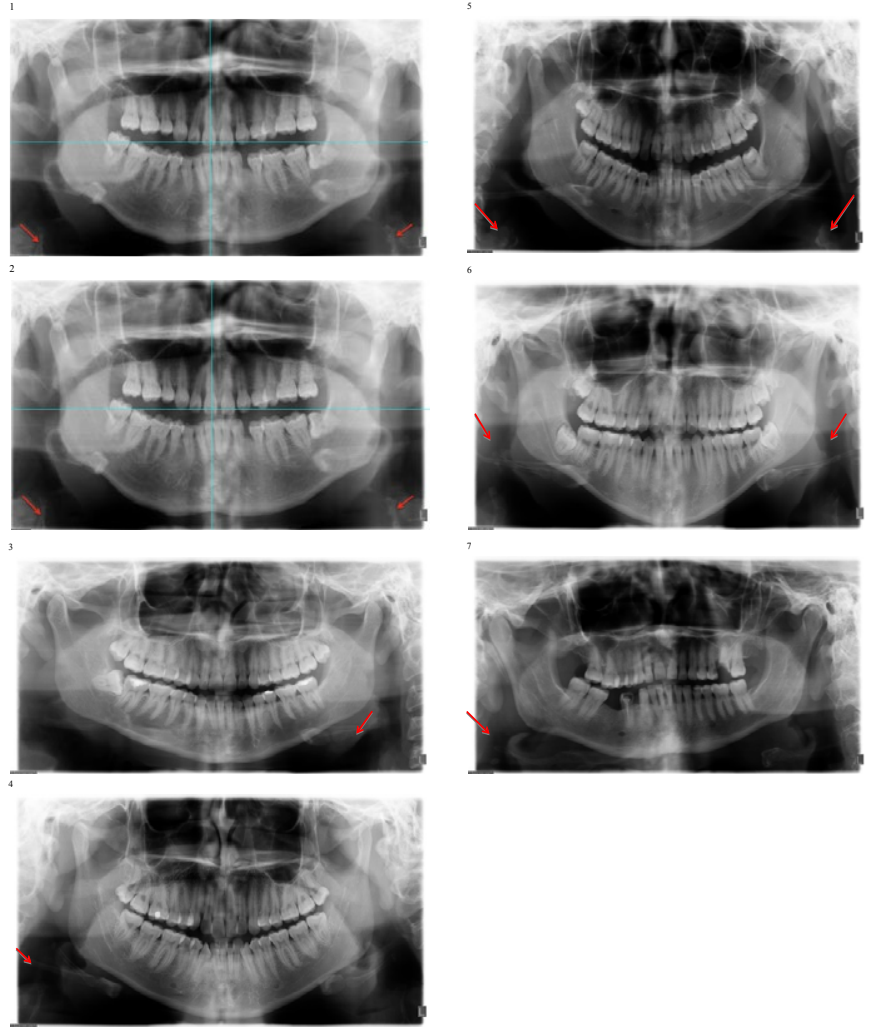

Figure 1. Patient 1-7.

\section{Discussion}

This study gives a good option to the Mexican population for the early diagnosis of calcified atheromatous plaques.

Salazar (2011) reported a study of 2995 radiographies with a prevalence of $3.07 \%$ in a population with a mean age of 45.3 years. The most of the cases were found mainly in men (56.1\%) while in our study the major prevalence was found in women (57.1\%).

About the localization of the calcifications, the same study by Salazar [6] reported unilateral findings in 31 patients (33.6\%) and bilateral findings in 61 patients $(66.3 \%)$. In our study, the bilateral findings were in three patients $(42.85 \%)$ and bilateral in four of them.

Friendlander and colls [5] performed a study in 1000 patients reporting a prevalence of $2 \%$ (5 cases), while these same authors in another study with 295 patients reported a prevalence of $3 \%$.The major part of the cases corresponded to male $69.3 \%$

In a more recent study by Friedlander [5] in 182 patients the reported prevalence was of $3.3 \%$ with 5 cases in males and female. The mean age of this population was $67.7 \%$, all these studies show an inverse relation between sexes compared with the results of the present study. Besides the mean age of these studies exceeds the one observed in this study, 31.8 years.

About the limitations of this study it is recognized that we did not perform any post processing of the image with the multiplanar reconstruction, as it is on in Tomography Axial Computed (TAC), or a doppler study, since the data taken for the study had not the original purpose of recognizing the atheromatous plaques; these are X-ray findings belonging to a routine process where the ortopantomographies 
are taken just as a request to be admitted in any of the dental clinics of the ENES. We recommended to our patients to attend to a hospital to be checked.

\section{Conclusion}

It was observed a low prevalence of carotid calcifications and most of them were found in women. To identify and determine the prevalence of carotid calcifications through the use of orthopantomography, contributes to an early diagnosis and to the prevention of these kinds of pathologies in patients under risk, preventing also the associated disabilities or death.

The use of this technology in the detection of carotid calcification is useful however it presents some limitation so that it is important the training of the future dentists on the detection of these pathologies to make the appropriate remission of the patients to a medical evaluation to avoid future complications.

\section{References}

1. Biermann EL (1994) Harrison's Principles of Internal Medicine por Kurt J. Isselbacher et al. (13a ed. U.S.A), 1106-1116, Mc Graw- Hill.
2. Guzmán D, Ximena Concha, Mauricio Rudolph, Carmen Lucía Guzmán. (2007) Aporte preventivo de Accidente Vascular Encefálico en Pacientes Sometidos a Exámenes Radiográficos en la Región Maxilofacial Revista Dental de Chile 99: 34-41.

3. Rocío Roldan Chicano, Ricardo E Oñate Sánchez, Fuensanta López Castaño, María del Carmen Cabrerizo Merino, Federico Martínez López (2006) La Ortopantomografía como método para la detección de las placas de ateroma calcificadas. Medicina oral. Patología oral y cirugía bucal 11: 167-173.

4. Rosamond W, Flegal K, Friday G, Furie K, Go A , et al. (2007) Heart disease and stroke statistics--2007 update: a report from the American Heart Association Statistics Committee and Stroke Statistics Subcommittee. Circulation 115: e69-171. [Crossref]

5. Friedlander AH, Lande A (1981) Panoramic radiographic identification of carotid arterial plaques. Oral Surg Oral Med Oral Pathol 52: 102-104. [Crossref]

6. Gloria Elena Salazar Arboleda, Francisco José Ponce Escobar, Rusvelt Vargas Moranth (2011) Detección de Placas de Ateroma Calcificadas en la Arteria Carótida en la Radiografía Panorámica. Revista Colombiana de Investigación en Odontología 2: 5.

7. Martínez RA, Chimenos E, López J (2005) Calidad de la ortopantomografía en la parte clínica. Radiología en Medicina Bucal. Chimenos E España, Masson 61-73.

8. Ravon NA, Hollender LG, McDonald V, Persson GR (2003) Signs of carotid calcification from dental panoramic radiographs are in agreement with Doppler sonography results. J Clin Periodontol 30: 1084-1090. [Crossref]

9. Carmen Cabrerizo Merino, Federico Martínez López. (2006) La Ortopantomografía como método de detección de las placas de ateroma calcificadas. Revisión de la literatura. Med Oral Patol Oral Cir Bucal 11: 261-266.

Copyright: $(02015$ Pineda GV. This is an open-access article distributed under the terms of the Creative Commons Attribution License, which permits unrestricted use, distribution, and reproduction in any medium, provided the original author and source are credited. 